\title{
Baseline characteristics of patients with non-valvular atrial fibrillation - single-centre registry
}

\author{
Charakterystyka hospitalizowanych chorych \\ z niezastawkowym migotaniem przedsionków - rejestr jednoośrodkowy
}

\author{
Iwona Gorczyca-Michta ${ }^{1}$, Beata Wożakowska-Kapłon ${ }^{1,2}$ \\ ${ }^{1}$ I st Cardiac Clinical Unit, Swietokrzyskie Cardiac Centre, Kielce, Poland \\ ${ }^{2}$ The Faculty of Medicine and Health Science, Jan Kochanowski University in Kielce, Poland
}

\begin{abstract}
Introduction. The evaluation of clinical profile of patients with atrial fibrillation (AF) is very important because it determines the choice of antithrombotic and anti-arrhythmic therapy. The presence of concomitant diseases, as well as the age and sex of patients with $\mathrm{AF}$, influence the risk of stroke.

The aim of the study was to analyse demographic data and assess the prevalence of concomitant diseases and the risk of thromboembolic and bleeding complications in hospitalized patients with AF.

Material and methods. Our study is a single-centre, retrospective registry. The analysis included data of 4,099 patients hospitalized in reference cardiology centre who were discharged with the diagnosis of AF in the years 2004-2012.

Results. The analysed group included 4,099 patients with AF; 2,244 study participants (54.7\%) were females. Mean age of whole study population was 70.6 years. Chronic AF was diagnosed in 1,875 patients (45.7\%). Paroxysmal AF occurred in 1,767 patients (43.1\%). The most frequent diseases that coexisted with AF in the study group were: hypertension in 3,067 patients ( $74.8 \%$ ), ischaemic heart disease in 2,324 patients (56.7\%), and heart failure in 2,247 patients $(54.8 \%)$. Among study participants, 297 patients (7.2\%) were free from risk factors of stroke $\left(\mathrm{CHADS}_{2}=0\right)$ ); 1,042 patients (25.4\%) had $\mathrm{CHADS}_{2}$ score of 1 and 2,760 patients (67.4\%) had $\mathrm{CHADS}_{2}$ score of 2 or more points.

Conclusions. In our registry of hospitalized patients with AF, the most prevalent group were elderly patients with many concomitant diseases that can be considered as a cause of arrhythmia, but also influence thromboembolic risk in these patients and determine the need for antithrombotic therapy.
\end{abstract}

Key words: atrial fibrillation, risk of stroke, registry

Folia Cardiologica 2016; 11, 2: 98-103

\section{Introduction}

Atrial fibrillation $(\mathrm{AF})$ is the most frequent chronic arrhythmia, affecting 1-1.5\% of global population [1]. In the United States, about 2.3 million people suffer from AF, while the number of patient with AF in Poland is about $400,000[2,3]$. It is estimated that, due to population ageing, resulting in more frequent occurrence of the diseases promoting $\mathrm{AF}$ development, the number of patients with arrhythmias will at least double by the year 2050 [4]. The increase in AF prevalence in recent years has been confirmed by the data from Spanish registry, showing $27 \%$ increase in $A F$

Address for correspondence: dr n. med. Iwona Gorczyca-Michta, I Klinika Kardiologii i Elektroterapii, Świętokrzyskie Centrum Kardiologii, ul. Grunwaldzka 45, 25-736 Kielce, e-mail: iwona.gorczyca@interia.pl 
prevalence during 10 years: from $4.8 \%$ in 1999 to $6.14 \%$ in 2009 [5]. The prevalence of AF increases with age; it is $0.1 \%$ in subjects younger than 50 years, whereas in patients above 85 years it rises to $17.8 \%$ [6]. The evaluation of clinical profile of patients with AF is very important because it determines the choice of antithrombotic and anti-arrhythmic therapy. The presence of concomitant diseases, as well as the age and sex of patients with AF, influence the risk of stroke. Among those diagnosed with AF, there are very few patients without comorbidities that are risk factors for thromboembolic events. According to data from REALISE-AF registry of 10,523 patients with AF, only in $5 \%$ patients no concomitant diseases were present [7].

The aim of the study was to analyse demographic data and assess the prevalence of concomitant diseases and the risk of thromboembolic and bleeding complications in hospitalized patients with AF.

\section{Material and methods}

Our study is a multicentre, retrospective registry. The analysis included data of 4,099 patients discharged from reference cardiology centre who were hospitalized in the years 2004-2012. Consecutive patients hospitalized for AF were included in the study. Included in the analysis were medical records with complete data allowing for the assessment of thromboembolic and bleeding complication risks according to currently used scales, as well as the data on recommended antithrombotic prophylaxis. For patients who were hospitalized more than once, only data concerning the last hospitalization were analysed. Exclusion criteria were valvular AF and in-hospital death.

The study included patients hospitalized in the years 2004-2012 when mainly $\mathrm{CHADS}_{2}$ scale was used and therefore this scale was utilised for thromboembolic risk assessment. $\mathrm{CHADS}_{2}$ score of 0 points means low thromboembolic risk, 1 point - moderate risk, and 2 points or more - high risk of stroke. Also $\mathrm{CHA}_{2} \mathrm{DS}_{2} \mathrm{VASc}$ score was used in the study. The risk of stroke assessed with this scale corresponds to $\mathrm{CHADS}_{2}$ score.

When assessing the risk of bleeding complication according to HAS-BLED score, following conditions were considered as promoting bleeding episodes: anaemia, defined as haemoglobin level below $13 \mathrm{~g} / \mathrm{dL}$ in women and below $12 \mathrm{~g} / \mathrm{dL}$ in men, and thrombocytopoenia below $150 \mathrm{G} / \mathrm{L}$. Labile international normalized ratio (INR) was defined as time in therapeutic range (TTR) below $60 \%$. Impaired kidney function was defined as creatinine levels $\geq 220 \mu \mathrm{mol} / \mathrm{L}$ or chronic dialysotherapy or previous kidney transplantation. Impaired liver function was defined as chronic liver disease or biochemically significant liver injury (bilirubin level $>$ than $2 \times$ upper limit of normal [ULN] or aminotransferase activity higher than $3 \times$ ULN).
The study was approved by regional Bioethics Committee (No 12/21011).

\section{Results}

The analysed group included 4,099 patients with AF; 2,244 study participants (54.7\%) were females. Mean age of whole study population was $70.6( \pm 10.9)$ years and it was $68.2( \pm 11.5)$ years in men and $73.5( \pm 9.4)$ years in women. There were 1,535 women ( $68.4 \%$ of all women) and 1,440 men ( $77.6 \%$ of all men) older than 65 years. Overall 2,975 patients $(72.6 \%)$ were above 65 years of age. There were 1,701 patients (41.5\%) older than 75 years (Fig. 1).

Patients with AF were hospitalized mainly to perform elective procedures: cardiac stimulation system implantation/reimplantation $-1,422$ patients $(34.7 \%)$, coronary angiography or coronary angioplasty -250 patients (6.1\%) or electrophysiology study and/or ablation - 57 patients (1.4\%). Aggravation of the underlying disease was the reason for hospitalization in 845 patients (20.6\%) with AF. Most of them (580 patients; $68.4 \%$ of patients hospitalized for underlying disease) presented with decompensation of heart failure caused by other condition than AF with rapid ventricular rate. AF with rapid heart rate was a reason for hospitalization in 127 patients (15\%), ischaemic heart disease aggravation - in 102 patients (12.1\%), and hypertensive crisis - in 36 patients (4.5\%). Angina pectoris was diagnosed in 142 patients, myocardial infarction without ST segment elevation - in 213 patients, and myocardial infarction with ST segment elevation - in 232 patients, that is in $24.2 \%, 36.3 \%$ and $39.5 \%$ patients with acute coronary syndrome, respectively.

The most common type of arrhythmia, observed in 1,875 patients (45.7\%), was chronic AF. Paroxysmal AF occurred in 1,767 patients $(43.1 \%)$. Thirty patients $(0.7 \%)$ had first detected AF. Persistent arrhythmia was observed in 426 patients $(10.4 \%)$.

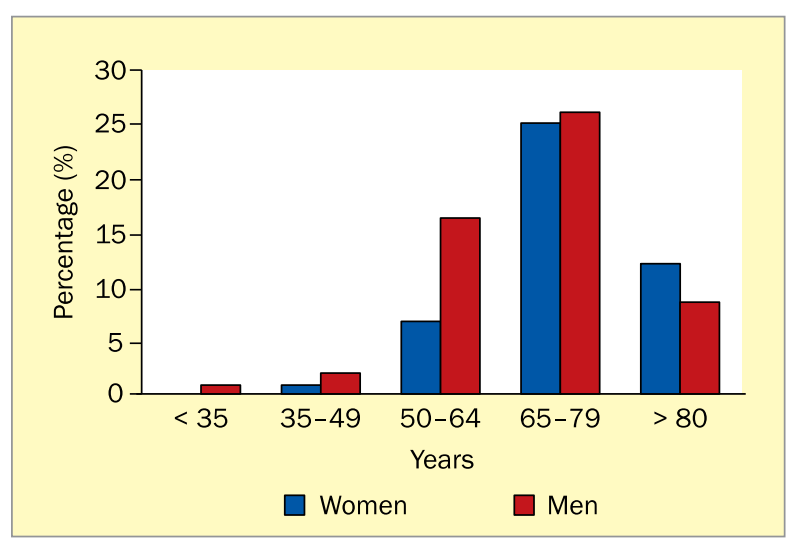

Figure 1. Age of patients with atrial fibrillation according to gender 
The most frequent diseases that coexisted with $\mathrm{AF}$ in the study group were: hypertension in 3,067 patients (74.8\%), ischaemic heart disease in 2,324 patients $(56.7 \%)$, and heart failure in 2,247 patients (54.8\%). Most patients with heart failure were in NYHA class II (1,130 patients, 50.3\% of patients with heart failure) and III (944 patients, $42 \%$ of patients with heart failure). Special attention should be paid to high prevalence of diabetes observed in 893 patients (21.8\%) and thyroid diseases - in 667 patients $(16.2 \%)$ (Tab. 1).

In the assessment of the risk of stroke, mean $\mathrm{CHADS}_{2} \mathrm{ScO}$ re in the study population was 2.2 points. Among study participants, 297 patients (7.2\%) were free from risk factors for stroke $\left(\mathrm{CHADS}_{2}=0\right)$. $\mathrm{CHADS}_{2}$ score values were as follows: 1,042 patients (25.4\%) had $\mathrm{CHADS}_{2}$ score of 1 and 2,760 patients $(67.4 \%)$ had $\mathrm{CHADS}_{2}$ score of 2 or more points. Figure 2 shows $\mathrm{CHADS}_{2}$ score in the study group.

Mean $\mathrm{CHA}_{2} \mathrm{DS}_{2} \mathrm{VASc}$ score in the study group was 3.7. Based on $\mathrm{CHA}_{2} \mathrm{DS}_{2} \mathrm{VASc}$ score, 127 patients (3.1\%) were considered as free from risk factors for stroke complications. Overall 364 patients (8.9\%) had $\mathrm{CHA}_{2} \mathrm{DS}_{2}$ VASc score of 1 point. Among them, there were 46 women (1.1 of study group) whose score was 1 due to female sex). There were 3,607 patients (88\%) with the $\mathrm{CHA}_{2} \mathrm{DS}_{2} \mathrm{VASc}$ score of 2 or more points. Figure 3 presents $\mathrm{CHA}_{2} \mathrm{DS}_{2} \mathrm{VASc}$ score in the study group.

Mean HAS-BLED score in the study group was 2.1 . Based on HASBLED score, 1,418 patients (34\%) were at high risk for bleeding and 2,681 patients $(65.4 \%)$ were at low risk for bleeding.

The risks of bleeding complications were compared between the groups of patients with low, moderate and high thromboembolic risk. High bleeding risk (HAS-BLED $\geq 3 \mathrm{pts}$ ) was found in 5 patients $(1.7 \%)$ with no risk factors for stroke, 143 patients (13.7\%) with moderate risk of stroke and 1,256 patients (45.5\%) with high risk of stroke (Fig. 4).

\section{Discussion}

The mean age of the patients included in our study $(n=$ $=4,099$ ) was 71 years. In this group, $42 \%$ of patients were older than 75 years, and every fifth patient was older than 80 years. Women were most prevalent in the study population (55\%). The mean age of the patient in our study was similar to that of patients in the first cohort of European GARFIELD Registry - 70 years [8]. The proportion of GARFIELD Registry patients older than 75 years is $39 \%$. Patients included in our study were younger than those included in the ATRIUM Registry (mean age 72 years) [9] and other patients hospitalized in District Hospital in Grodzisk Mazowiecki, Poland, (mean age 74 years) [10]. On the other hand, our patients were younger than patients included in Euro Heart Survey on Atrial Fibrillation Registry (mean age 68 years) [11], AFNET registry (mean age 68 years) [12] and
Table 1. Clinical characteristics of study population with atrial fibrillation

\begin{tabular}{|c|c|c|}
\hline Clinical features & $\begin{array}{l}\text { Number } \\
\text { of patients } \\
n=4099\end{array}$ & $\begin{array}{l}\text { Percentage } \\
\text { of patients } \\
(\%)\end{array}$ \\
\hline \multicolumn{3}{|c|}{ Concomitant diseases } \\
\hline Hypertension & 3067 & 74.8 \\
\hline Ischaemic heart disease & 2324 & 56.7 \\
\hline Prior myocardial infarction & 1116 & 27.2 \\
\hline Acute coronary syndrome & 587 & 14.7 \\
\hline Prior coronary angioplasty & 633 & 15.4 \\
\hline $\begin{array}{l}\text { Prior arterial by-pass } \\
\text { grafting }\end{array}$ & 152 & 3.7 \\
\hline Heart failure & 2247 & 54.8 \\
\hline $\begin{array}{l}\text { Renal insufficiency } \\
\text { (GFR }<60 \mathrm{ml} / \mathrm{min} \text { ) }\end{array}$ & 2206 & 53.8 \\
\hline Dyslipidaemia & 1897 & 46.3 \\
\hline Hypercholesterolaemia & 1307 & 31.9 \\
\hline Hypertriglyceridaemia & 213 & 5.2 \\
\hline Combined hyperlipidaemia & 377 & 9.2 \\
\hline Type 2 diabetes & 893 & 21.8 \\
\hline Thyroid diseases & 667 & 16.2 \\
\hline Hyperthyroidism & 304 & 7.4 \\
\hline Hypothyroidism & 202 & 4.9 \\
\hline $\begin{array}{l}\text { Nodular goitre with } \\
\text { euthyreosis }\end{array}$ & 161 & 3.9 \\
\hline $\begin{array}{l}\text { Chronic obstructive } \\
\text { pulmonary disease }\end{array}$ & 337 & 8.2 \\
\hline Neoplastic disease & 173 & 4.2 \\
\hline Gastric/duodenal ulcer & 169 & 4.1 \\
\hline $\begin{array}{l}\text { Lower extremity } \\
\text { atherosclerosis }\end{array}$ & 79 & 1.9 \\
\hline \multicolumn{3}{|c|}{ Thromboembolic complication } \\
\hline Prior stroke & 434 & 10.6 \\
\hline Prior TIA & 59 & 1.4 \\
\hline Prior peripheral embolism & 80 & 2 \\
\hline \multicolumn{3}{|c|}{ Electrophysiological interventions } \\
\hline Pacemaker implantation & 1721 & 42 \\
\hline $\begin{array}{l}\text { Cardioverter-defibrillator } \\
\text { implantation }\end{array}$ & 141 & 3.4 \\
\hline CRT system implantation & 15 & 0.04 \\
\hline
\end{tabular}
emic attack

REALISE-AF trial [7]. This may be caused by the fact that these registries included both inpatients and outpatients, while in our paper only hospitalized patients were analysed. Women were $55 \%$ of patients with AF hospitalized in Kielce Centre, whereas in cited registries women were in 


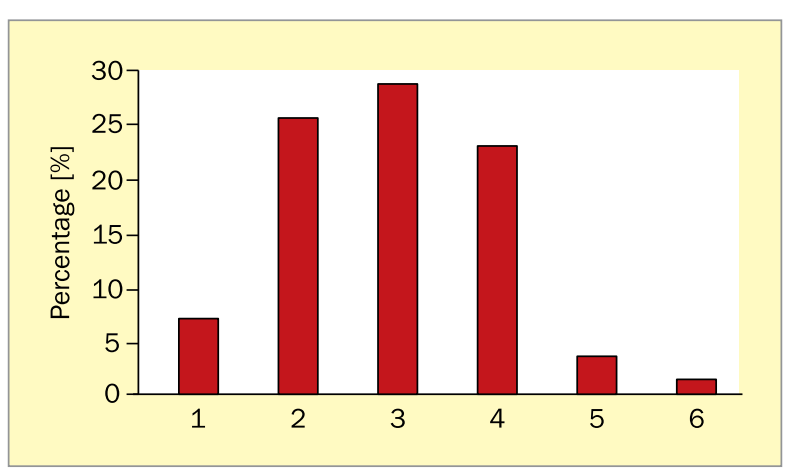

Figure 2. $\mathrm{CHADS}_{2}$ score in the study group

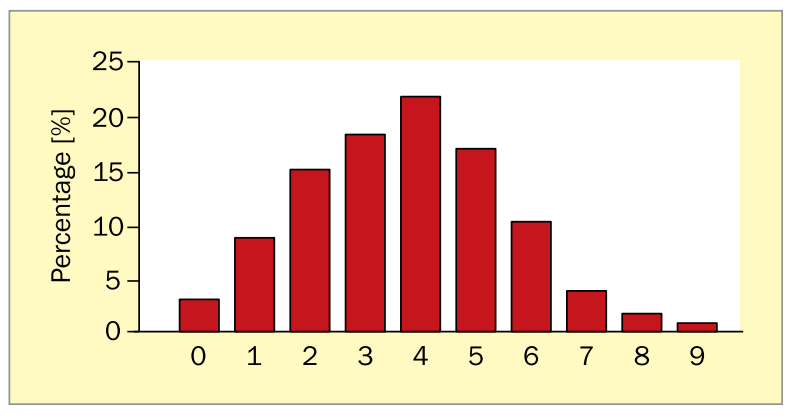

Figure 3. $\mathrm{CHA}_{2} \mathrm{DS}_{2} \mathrm{VASc}$ score in the study group

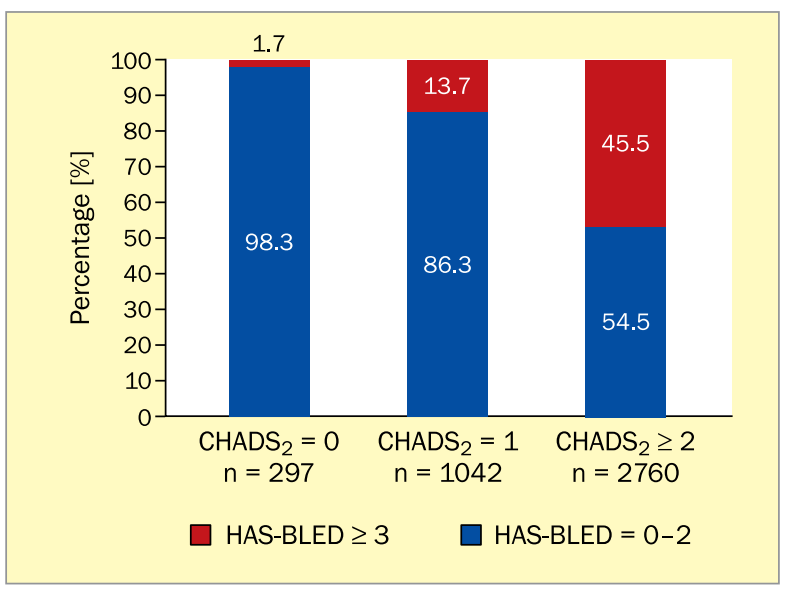

Figure 4. Risk of bleeding complications in patients with low, moderate and high risk of stroke

registries, and to the fact that $\mathrm{AF}$ prevalence is higher in elderly women than in elderly men, which is related to longer life-span of women.

The percentage of patients with persistent AF in the population of our study was as low as $10 \%$. Bednarski et al. [10] obtained similar results; he reported persistent AF in $12 \%$ of studied patients. In a study including 1,559 patients hospitalized in Bialystok centre, persistent AF was found in $17 \%$ of patients [13]. Finally, persistent AF was found in $22 \%$ patients participating in the Euro Heart Survey on Atrial Fibrillation trial [11] and in 27\% patients in ATRIUM registry [9]. There are also similar discrepancies in reported rate of first detected AF. In our study, this form of arrhythmia was found in only $0.7 \%$, whereas in the AFNET registry of patients treated in hospital and outpatient condition, the percentage of patients with first detected AF was $11 \%$ [12]. Our study included only patients hospitalized in cardiology department, whereas in patients with first detected AF return to normal sinus rhythm due to pharmacological cardioversion is usually obtained at the emergency care unit. Moreover, those with first detected AF, particularly young patients without comorbidities, are also hospitalized in the departments of internal diseases or treated on an outpatient basis. In our study, almost half of the patients (46\%) had persistent form of arrhythmia, which probably reflected advanced age of study participants and the presence of concomitant diseases. Similar percentage of patients with persistent AF was found in the ATRIUM (42\%) [9] and REALISE-AF (46\%) [7] trials. Contrary, in the Euro Heart Survey on Atrial Fibrillation trial, the proportion of patients with chronic AF was 29\% [11].

In our study, 75\% AF patients had underlying hypertension. Similarly, in the GARFIELD registry $78 \%$ subjects had a history of hypertension [8]. Higher proportion of AF patients with hypertension was noted in the ATRIUM registry (84\%) [9], and lower - in the European registry (62\%) [11] and the AFNET trial (69\%) [12]. Worth noting is high percentage of patient with AF and heart failure (55\%) compared with other registries. Higher than in our study proportion of patients with heart failure (62\%) was shown in the study performed in a district hospital. In the GARFIELD registry heart failure was diagnosed in $21 \%$ of patient with AF. The patients included in the GARFIELD registry are at similar age as the patients in our study; however, the lower prevalence of heart failure in the GARFIELD registry population may result from the fact that it includes the patients with first diagnosed AF [8]. Lower proportion of patients with heart failure was also found in the Euro Heart Survey on Atrial Fibrillation trial, which may be attributed to younger age of the patients and considerably lower percentage of patients with chronic AF than in our study (29\% vs $46 \%$ ). High percentage of hospitalized patients with heart failure observed in the study performed in Świętokrzyskie Centre is associated with the profile of this centre. The most numerous group were the patients hospitalized in order to perform elective procedures, including implantation and reimplantation of cardioverters-defibrillators or cardiac resynchronisation systems. This is the only centre in the region where implantations of cardiac resynchronization therapy systems are performed. Furthermore, patients with heart failure were the most numerous group of patients hospitalized for exacerbation of underlying disease (68\%). 
In our study, the underlying ischaemic heart disease was found more frequently in patients with AF compared with other registries: $57 \%$ vs $19 \%$ (GARFIELD), $28 \%$ (AFNET), 32\% (Euro Heart Survey on Atrial Fibrillation) and $35 \%$ (ATRIUM). This might result from 24-hour access to haemodynamics laboratory and hospitalization of patients with acute coronary syndromes who were also referred from other centres in the region. In these patients ischaemic heart disease often led to heart failure.

Mean $\mathrm{CHADS}_{2}$ score in the population of our study was 2.2. Among study participants, $7 \%$ were free from risk factors for stroke, $26 \%$ had $\mathrm{CHADS}_{2}$ score of 1 point, and in $67 \% \mathrm{CHADS}_{2}$ score was 2 or more. Similar mean $\mathrm{CHADS}_{2}$ score was obtained in the ATRIUM trial [9]. Bednarski et al. [10] found high thromboembolic risk in $85 \%$ of analysed population, and there were only $2 \%$ of patients with no risk factors for stroke. Similar results were reported by Łopatowska et al. [13] who analysed 1,559 patients with both valvular and non-valvular AF and found that only $3 \%$ of patients were free from risk factors for stroke. Conversely, in the Euro Heart Survey on Atrial Fibrillation there were as many as $18 \%$ of patients in whom no thromboembolic risk factors were found, and $49 \%$ of patients were considered as having high-risk for stroke [11]. In a group of Polish pa- tients included in the GARFIELD registry, low risk of stroke was found in $4.4 \%$ patients in the first cohort and $5.5 \%$ patients in the second cohort, moderate risk - in 38.7\% patients in the first cohort, $39.8 \%$ patients in the second cohort 2, and high risk in $56.9 \%$ and $54.7 \%$ of patients, respectively [14].

In our study, only small percent of patients had isolated $\mathrm{AF}$, which was consistent with the results obtained by other authors. The vast majority of patients with arrhythmia had comorbid conditions that contributed to significant thromboembolic risk in these patients.

\section{Conclusions}

In our registry of hospitalized patients with AF, the most prevalent group were elderly patients with many concomitant diseases that can be considered as a cause of arrhythmia, but also influence thromboembolic risk in these patients and determine the need for antithrombotic therapy.

\section{Conflict of interest(s)}

None declared.

\section{Streszczenie}

Wstęp. Ocena profilu klinicznego chorych z migotaniem przedsionków (AF) jest niezwykle istotna, ponieważ zależy od niej postępowanie przeciwkrzepliwe i antyarytmiczne. Obecność schorzeń współistniejących, wiek i płeć u chorych z AF wpływają na ryzyko powikłań zakrzepowo-zatorowych.

Celem pracy jest analiza danych demograficznych, ocena częstości występowania schorzeń współistniejących oraz ryzyka zakrzepowo-zatorowego i ryzyka powikłań krwotocznych u hospitalizowanych chorych z AF.

Materiał i metody. Prezentowane badanie jest jednoośrodkowym, retrospektywnym rejestrem. Analizą objęto dane 4099 pacjentów wypisanych z kliniki kardiologii ośrodka referencyjnego w latach 2004-2012 z rozpoznaniem AF.

Wyniki. W analizowanej grupie obejmującej 4099 chorych z AF kobiety stanowiły 2244 badanych (54,7\%). Średnia wieku pacjentów wynosiła 70,6 roku. Utrwalone AF występowało u 1875 chorych (45,7\%), a napadowe AF stwierdzono u 1767 chorych (43,1\%). W badanej grupie z AF najczęściej współistniały nadciśnienie tętnicze - u 3067 chorych (74,8\%), choroba niedokrwienna serca - u 2324 chorych (56,7\%) oraz niewydolność serca - u 2247 chorych (54,8\%). W badanej grupie u 297 pacjentów $(7,2 \%)$ nie stwierdzono czynników ryzyka powikłań zakrzepowo-zatorowych (CHADS 2 = 0 pkt.). U 1042 pacjentów (25,4\%) stwierdzono wynik w skali CHADS 2 równy 1, a u 2760 pacjentów (67,4\%) wynosił on 2 i więcej punktów.

Wnioski. W prezentowanym rejestrze hospitalizowanych chorych większość pacjentów z AF stanowiły osoby w podeszłym wieku z licznymi współistniejącymi schorzeniami, które jednocześnie można uznać za przyczynę wystąpienia arytmii i które wpływają na ryzyko zakrzepowo-zatorowe u tych chorych, decydując o konieczności stosowania leczenia przeciwkrzepliwego.

Słowa kluczowe: migotanie przedsionków, ryzyko zakrzepowo-zatorowe, rejestr

Folia Cardiologica 2016; 11, 2: 98-103 


\section{References}

1. Chen L.Y., Shen W.K. Epidemiology of atrial fibrillation: a current perspective. Heart Rhythm 2007; 4: 1-6.

2. Lloyd-Jones D., Wang T., Leip E. et al. Lifetime risk for development of atrial fibrillation: the Framingham Heart Study. Circulation 2004; 110: 1042-1046.

3. Pruszczyk P. Stępińska J. Banasiak W. et al. Zastosowanie nowych doustnych leków przeciwkrzepliwych w prewencji powikłań zatorowych u chorych z migotaniem przedsionków. Kardiol. Pol. 2012; 70: 979-988.

4. Heeringa J., van der Kuip D.A., Hofman A. et al. Prevalence, incidence and lifetime risk of atrial fibrillation: the Rotterdam study. Eur. Heart J. 2006; 27: 949-953.

5. Rodríguez-Manero M., Bertomeu-González V., Cordero A. et al. Trends in clinical profile and medical treatments of atrial fibrillation patients over the last 10 years. Rev. Port. Cardiol. 2013; 32: 103-109.

6. Feinberg W.M., Blackshear J.L., Laupacis A. et al. Prevalence, age distribution, and gender of patients with atrial fibrillation. Analysis and implications. Arch. Intern. Med. 1995; 155: 469-473.

7. Alam M., Bandeali S.J., Shahzad S.A. et al. Real-life global survey evaluating patients with atrial fibrillation (REALISE-AF): results of an international observational registry. Expert Rev. Cardiovasc. Ther. 2012; 10: $283-291$.

8. Kakkar A.K., Mueller I., Bassand J.P. et al. Risk profiles and antithrombotic treatment of patients newly diagnosed with atrial fibrillation at risk of stroke: perspectives from the international, observational, prospective GARFIELD registry. PLoS One 2013; 8: e63479.

9. Meinertz T., Kirch W., Rosin L. et al. Management of atrial fibrillation by primary care physicians in Germany: baseline results of the ATRIUM registry. Clin. Res. Cardiol. 2011; 100: 897-905.

10. Bednarski J., Cieszewska E., Strzelecki A., Filipiak K.J. Anticoagulant and antiplatelet therapy for stroke prevention in atrial fibrillation patients in the clinical practice of a single district hospital in Poland. Kardiol. Pol. 2013; 71: 1260-1265.

11. Nieuwlaat R., Capucci A., Camm A.J. et al. Atrial fibrillation management: a prospective survey in ESC member countries: the Euro Heart Survey on Atrial Fibrillation. Eur. Heart J. 2005; 26: 2422-2434.

12. Nabauer M., Gerth A., Limbourg T. et al. The Registry of the German Competence NETwork on Atrial Fibrillation: patient characteristics and initial management. Europace 2009; 11: 423-434.

13. Lopatowska P., Tomaszuk-Kazberuk A., Mlodawska E. et al. Management of patients with valvular and non-valvular atrial fibrillation in Poland: results from Reference Cardiology University Centre. Cardiol. J. 2015; 22: 296-305.

14. Stępińska J., Kremis E., Konopka A. et al. Stroke prevention in AF patients in Poland and other European countries: insights from the GARFIELD-AF registry. Kardiol. Pol. 2015 Sep 14. doi: 10.5603/ /KP.a2015.0173 [Epub ahead of print]. 